\title{
An Empirical Research Survey of the Productivity and Efficiency of the Securities Industry
}

\author{
My $\operatorname{Tran}^{1} \&$ Malcolm Abbott ${ }^{1}$ \\ ${ }^{1}$ Faculty of Business and Law, Swinburne University of Technology, Melbourne, Australia \\ Correspondence: Malcolm Abbott, Faculty of Business and Law, Swinburne University of Technology, Melbourne, \\ Australia.
}

Received: January 4, 2021

Accepted: March 3, 2021

Available online: March 10, 2021

doi:10.11114/aef.v8i2.5185

URL: https://doi.org/10.11114/aef.v8i2.5185

\begin{abstract}
This paper provides a review of the approaches that have been used to evaluate the productivity and efficiency of the securities industry (financial ratios, econometric techniques, data envelopment analysis-DEA, and the estimation of stochastic frontiers). In undertaking this it identifies some of the organisational structure characteristics of securities companies that are associated with high levels of operational efficiency, particularly regarding the impact of regulation, the structure of ownership, and economies of scope and scale. The findings are that from the limited number of studies that have to date been undertaken it appears that the industry does have economies of scale, benefits from deregulation and performs better with foreign and bank ownership.
\end{abstract}

Keywords: securities companies; productivity; efficiency; economies of scale and scope

\section{Introduction}

Over the years, a great deal of analytical research has been carried out involving the measurement of the productivity and efficiency of a number of industries, in particular involving industries in the United States. Some of this research has undertaken on the financial industry, however, there has only been a small number of works of this sort carried out on the performance of the securities industry. In the case of the securities industry, this research has been motivated by the desire to evaluate the impact of the deregulation of the securities industry in a number of countries, as well as to determine what the benefits are of the industry to certain groups of people such as regulators, investors, and creditors.

In general, the most common form of empirical study undertaken on the performance of the securities industry has been the use of financial ratios, although econometric techniques, which involve the estimation of industry cost/production functions have also been used along with Data Envelopment Analysis (DEA) and Stochastic Frontier Analysis. These various approaches have been used to evaluate the degree to which the securities industry is the subject of such things as economics of scope and scale, or to comment on a variety of other issues. Evaluating the productivity/efficiency levels of the securities industry has been encouraged by the pooling of data, which has occurred in several countries.

Initially the studies of the productivity/efficiency levels of the securities firms in the United States became common after the deregulation of the industry in 1975, which involved the unfixing of commission rates. Other notable deregulatory measures were undertaken, such as the financial "Big Bang" 1986 in the United Kingdom and in 1997 to 1999 deregulation of the industry in Japan. These changes helped to alter the structure of financial markets in both London and Tokyo, as did a range of other factors such as mergers and acquisition, the introduction of new technology, and changes in ownership structures. Reform of the industry has meant that in the researchers became motivated to undertake research into the productivity and efficiency of financial institutions, including the securities companies, in a range of countries. In terms of the securities industry a list of the major studies that have been undertaken in different countries is provided in Table 1.

Considering the results of these various studies, this paper has two main objectives. First, the various methods used are reviewed to examine just what approaches to determining the productivity/efficiency performance of the securities companies have been used (financial ratios, econometric techniques, and data envelopment analysis-DEA). Secondly, and more importantly, this paper uses these studies to identify the organisational structure characteristics that are most associated with high levels of operational efficiency, especially in respect of the impact of regulation, ownership 
structures, and the economies of scope and scale. These findings would be of interest of investors in securities companies and regulators

The outline of this paper is as follows. In the first section of the paper there is provided a brief overview of the main material studied is provided (the securities industry), followed by the area description, that is an identification of the main approaches, used to evaluate productivity/efficiency levels in the securities industry. This is followed by a section, which gives the results of that have arisen from this empirical research. This section of the paper is divided into three sections ( 1 - whether economies of scale and scope exist; 2 - the influence of ownership structure, and 3 - the impact of regulation on efficiency). In the following section of the paper a discussion is provided of the key findings of this research, and in the final section some comments are made on the issues that would warrant future research.

\section{Main Material: The Securities Industry}

The securities industry plays an important part of financial markets, along with that of the banking industry. Securities companies typically deliver a variety of products and services, including amongst them brokerage services, financial advisory services, the underwriting of new share issues, proprietary trading, and asset/wealth management (see Figure 1 for the income composition of different products/services provided by the securities industry in a range of countries). Brokerage services are where securities companies act as a broker of behalf of customers, especially in the selling and buying of stocks and other securities. Underwriting services are the act of undertaking to buy, at an agreed price, any unsold part of a public shares issue. Proprietary trading can be understood to be where a trader buys/sells bonds, currencies, stocks, commodities, and the derivatives of other financial instruments with a company's own money. Asset/wealth management is an advisory function, which incorporates financial planning and investment portfolio management. In addition, securities companies can also provide other financial advisory services.

As already mentioned, one of the main sources of income of securities companies are the commissions, that are earnt from the provision of brokerage services. Any change, therefore, of regulation, such as the abolition of brokerage commission regulation, can have a significant impact on the financial returns of securities firms. For instance, the deregulation in 1975 in the United States of commission rates, and the relaxing of regulation in the British and Japanese industries (1986 and 1997 to 1999 respectively), all led to substantial changes in the securities services industry, both in term of profitability and industry structure.

In these cases of deregulation, the structure of the securities industry was altered in a number of ways. In several countries, mergers and acquisitions subsequently took place, firm activities changed, and competition with other industries was intensified. This intensified competition has meant that brokerage commission rates have generally declined, along with commission income as a proportion of total firm revenue (see the case of the United States shown in Figures 2 and 3).

In addition to these changes, the development and increased use of new technologies in the in the securities industry has given companies more capacity to deliver a wider range of services to customers. The techniques of securitisation, programmed trading, and complex debt swaps are now a part of the day-to-day activities of the securities industry. Additionally, new entrants have come into the industry, in some cases causing a blurring of the lines between different types of companies in the financial services industry. It can see from Table 2A and 2B, for instance, that the services provided by the different groups of financial institutions, including securities companies, are today very much more similar to each other than they were back in the 1950s.

\section{Area Description: Method}

As regulatory reform has taken place in a number of countries, as well as technological change introduced, the structure of the industry has been altered. This has encouraged several researchers to undertake studies, in a range of countries, of the productivity/efficiency performance of the securities industry. In carrying out these studies, these researchers have utilised a number of productivity/efficiency analytical methods. Overall, it is possible, in light of these studies, to come to some tentative conclusions about the basic character of the industry, which is of interest to those who regulate the industry, invest in it, or act as creditors to it (along with industry managers as well).

\subsection{Financial Ratios}

The first approach used to analyse the performance of companies in the securities industry has been the use of financial ratios. Financial ratios have been used by some researchers to examine the change of companies' performance over time, both before and after changes of the structure of companies (such as through mergers and acquisitions, expansion, and technological improvements), or changes in regulation. The major financial ratios preferred by researchers include such things as the Cost of Equity and Capital, the Return on Assets, Capital and Equity, Profitability, Average Costs and Revenue.

The use of financial rati0s has been used in a number of studies to examine the productivity and efficiency of securities 
companies. Most researchers first calculated financial ratios for the industry (or firms) and then ran OLS regressions to test their hypothesis. These studies include those by McCauley and Zimmer (1991), Chen et al. (2005), Liu (2007), Song et al. (2012), Bartholdy and Feng (2013), and Nguyen et al. (2017).

\subsection{Econometric Measures}

In addition to financial ratios, another long-used technique in studies on the securities industry is that of econometric estimation. These studies generally involve the estimation of cost functions, such as multiproduct, translog cost function, and partial translog cost functions. This method is one of the most common ones, which has been applied to investigating the securities industry's productivity and efficiency levels.

More specifically a number of studies applied econometric analysis of cost functions to examine whether economies of scales and scopes were important in the securities industry. Goldberg et el. (1991); Harimaya and Okuyama, (2006); Lee et al., (2014) and Liao (2018) all used this method for determining the companies' size (or market share) of productivity and efficiency change. In addition, Chen, Qi and Lin (2011) used econometric methods to measure the efficiency of different ownership structures and corporate governance arrangements amongst securities companies.

\subsection{Data Envelopment Analysis}

In more recent times another commonly used method of analysis is that of data envelopment analysis (DEA). This is a linear programming method, considered an appropriate technique for estimating the levels of efficiency in securities companies. In is often used as securities firms have multiple inputs and outputs, a situation, which DEA is particularly useful in analysing. When used, DEA produces a single score (a ratio of aggregated outputs to inputs) for each company, which can be used for comparison among a sample group.

DEA has in the past been utilised to access the productivity/efficiency of the securities industry at both the company and industry level. Research that in the past that has utilised DEA has focused on a number of issues including: Fukuyama and Weber (1999 and 2008) on cost efficiency in Japan; Zhang et al. (2006) on the productivity of the industry in United States; Hu and Fang (2010a, 2010b) on the efficiency of foreign affiliated ownership in Taiwan; Yeh et al. (2010) on size and efficiency in Taiwan; Bayyurt and Akin, (2014) on the efficiency of the acquisition of companies in Turkey; and Demirbag et al. (2016) on the size and efficiency in economies of scales of companies in Turkey. The various studies carried out on the securities industry, and the methods in each case used to investigate the productivity and efficiency of the securities industry, along with the data in each study used is briefly summarised in the Table provided in the Appendix.

\section{Results}

Looking at the list of the studies conducted and provided in the summary in the Appendix it is possible to review the results. These results focus on various themes and findings. These include:

- whether economies of scale and scope exist in the industry;

- where ownership structure affects productivity and efficiency; and

- whether regulation has an impact of efficiency.

\subsection{Scale and Scope Economies}

To begin with researchers have taken up the issue of whether scope and scale economies exist in the industry. Scale economies exist where the costs per unit of an output decrease as the level of output rises. In other words, the reduction in the cost of providing trading and other transaction services takes place because of a rise in efficiency when companies deliver more of these services (Lange et al., 2015). This normally occurs where a firm/industry has high fixed costs, as well as constant marginal costs, or alternatively low fixed costs and falling marginal costs. Research on the possible existence of economies of scale is of particular relevance to the securities industry, since this industry can provide a wide range of services to number of customers based on a pool of information collected. Related to scale economies are scope economies. Scale economies refer to the efficiencies gained through achieving larger levels of output of a single product, whereas scope economies are a reference to the efficiencies that can be created through the cost savings achieved by combining processes in the production of multiple outputs.

Size and technological improvement are major factors, favouring the cost saving structure of securities companies, through the achievement of either economies of scale or scope. Lange et al (2015) stated that if invested technology reduced the average cost of financial service production (such as securities underwriting, funds management and brokerage), larger companies might enjoy economies of scale, compared to smaller companies. In addition, many financial products have interrelationships to each other that encourage companies to make joint use of the same technology in producing multiple products. This process conceptually helps companies to save costs in production, and hence to achieve economies of scope, although, there are only a small number of studies that focus on this aspect in 
non-bank financial services companies (insurance companies, thrifts, and securities companies). These studies include those by Berger, Humphrey and Pulley (1996), along with Cummins, Tennyson and Weiss (1999).

Regarding the securities industry a few studies have found that there are greater economies of scale, less average unit costs, and more diversification with larger companies (see Fukuyama and Weber 1999, 2008; Johnston and Madura 2000; Demirbag et al. 2016; Le, Kim and Kang 2014; Nguyen, Nguyen, Nguyen and Tran 2017; Hu and Fang 2010a, 2010b; Liao 2018). On the other hand, there have been some studies that have shown more adverse results. For instance, Goldberg et al. (1991) found that small firms had economies of scale, whereas large and more diverse firms had diseconomies of scale. In addition, it was reported that economies of scope were unimportant in the industry in the early 1980s in the United States. The same result was found by Harimaya and Okuyama (2006), in that small online companies had a significant correlation with economies of scale. Yeh, Wang, and Chai (2010) also found that there was no correlation between large firms and levels of efficiency in the Taiwan securities industry.

\subsection{Ownership Structure}

The second issue considered by a few past studies was the influence of alternative ownership structures on the efficiency levels of securities firms. Ownership structure can be classified in various ways; such as in terms of government (state-owned) versus private ownership, foreign versus domestic ownership, and in terms shareholder ownership concentration. A number of studies found that there is a correlation between firm performance and major shareholder ownership. Ownership concentration, it was found, influenced the performance of the companies by controlling the level of agency problems (Shleifer and Vishny, 1986; Mínguez-Vera and Martín-Ugedo, 2007; Omran, Bolbol and Fatheldin, 2008; Nguyen et al., 2017; Gaur, Bathula, and Singh, 2015; Villalonga and Amit, 2006).

The level of stocks held by insiders can also have an influence on the companies' performance. There is evidence that shows an adverse effect on the performance of securities companies by insider ownership. The level of ownership of insiders has a relationship with the shareholder's objectives (Jensen and Meckling, 1976) and level of agency problems (Morck, Shleifer and Vishny, 1988; Nguyen et al. 2017). Thus, it can have an impact on a firm's performance.

Some of the studies that have been undertaken have investigated the relative effect of government-owned ownership versus private ownership on the performance of securities companies. Chen et al. (2005), and Nguyen et al. (2017), for instance, in their study came to the conclusion that government-ownership negatively affected the performance of securities companies. Hu and Leung (2012) found that government-owned companies performed less effectively compared to privately owned ones. One of the reasons, which explains this finding is the principle-agency problem. The results were found significant in countries with emerging economies such as Vietnam and China.

In terms of private ownership, companies can be categorised into two different structures - foreign and domestic owned. Both governance structures may have a potential impact on productivity/efficiency performance. A number of empirical studies have shown that foreign ownership had an impact on performance for companies in the finance sector, especially banks (see for instance Sabi, 1996; Guerra and Webber, 1999; Akin et al. 2003; Choi and Hasan, 2005; Barros, Ferreira, and Williams, 2007; Kasman and Yildirim, 2006; Lensick and Naaborg, 2007; Isik and Hassan, 2002). Only a few studies, however, have been undertaken for securities companies that address this this issue. Demirbag et al. (2016) discovered that foreign ownership positively impacted the efficiency of companies. This finding was supported by the studies of Nguyen et al. (2017) and Bayyurt and Akin (2014).

The business activities of securities companies can attract investment from banks; both domestic and foreign owned (Whalen, 1999). Banks may find potential benefits from investing in securities companies if they take companies over and reduce risks through diversification and gain efficiency through economies of scale (Demirbag et al. 2016). In contrast, securities companies also can potentially gain by being acquired by banks in that they may acquire better management access to finance. This assumption was found to be the case in the studies of Johnston and Madura (2000), Demirbag et al. (2006), and Nguyen et al. (2017).

\subsection{Regulation}

The third major concern taken into consideration by researchers into the securities industry is the effect of regulation on the industry. There are different regulation types, which can be implemented in order to enhance the net social welfare benefits of the provision of financial services. These potentially include such things as the measures undertaken to promote the prudential soundness of the industry, use of monetary policy, implementation of consumer and investor protection regulations, credit allocation regulation, and entry regulation (Saunders and Cornett, 2017). In addition, depository institutions (banks, building societies and credit unions) are often regulated heavily by regulators, while non-depository institutions, for example investment banks and securities companies are generally the subject of much fewer regulations. Any change in regulations can lead to an impact on the finance sector's productivity/efficiency. The impact of regulations can be seen in various aspects, such as companies' operation, cost of capital, market share, firm size, revenue, and governance structure. There are a few studies that look at the effect of regulation on the performance 
of securities companies. The findings of these studies found that regulation leads to both positive and negative impacts on the productivity and efficiency of securities companies.

One of the requirements of regulators for financial institutions is that they keep minimum levels of either 9or both) capital and equity. The levels of capital required can vary between countries, therefore, the different cost of capital may lead to differences in competitive advantages. McCauley and Zimmer (1991) investigated the relationship between the cost of capital and performance of United States and Japanese securities companies. They found that in the United States companies subjected to a high capital requirement, compared to those in the Japanese market, led them to have a disadvantaged position in competition. Another type of regulation are the restraints imposed on entry into the industry. Chen et al. (2005) looked at Chinese securities companies and found that the regulatory control of entry into the industry (qualifications) improved the performance of securities companies.

In a study on the effect of the bubble economy on the productivity/efficiency of Japan's securities companies, Fukuyama and Weber (1999) found that the Japanese central bank's expansionary monetary policy was one of the major reasons for the collapsed economy in the early 1990s. They found that deregulation can lead to greater cost efficiencies being achieved and that larger sized companies can have a cost efficiency advantage over smaller ones. Harimaya and Okuyama (2006) examined the change in the securities industry's structure after the financial Big Bang in Japan. They found that one impact of deregulation was the creation of online companies with economies of scales. Goldberg et al. (1991) undertook a study of the securities industry in the United States and found that if the regulations (Glass-Steagall) were relaxed, companies would gain higher revenue in brokerage. The evidence was that the top ten companies' revenues increased and accounted for sixty percent of overall industry's value in the years after deregulation (O'Brien, 1986). In addition, Steeley (1992) found a positive effect of deregulation on information efficiency through the reduction of transaction cost and the improved operational efficiency of the gilt-edged market. In contrast, Liu (2007) discovered that the stock performance of capital market of securities companies in Japan tended to decline as the deregulation proceeded.

\section{Conclusion}

In recent years, interest has risen amongst academic researchers about the structural reform of the finance sector. One manifestation of this trend is the growing number of studies that look at the productivity and efficiency performance of institutions in the finance sector. These studies, however, have tended to focus on the banking industry, although some studies have also been undertaken that look at the securities industry. In this paper, a review has been presented of the varied approaches that have been used in the past to evaluate the levels of productivity/efficiency in the securities industry and to summarise some of the main conclusions of these studies.

The work to date suggests some of the general characteristics in the securities industry that are associated with higher levels of productivity/efficiency. Firstly, the industry does exhibit economies of scale and this phenomenon is related to companies' size and technological improvements. Most of empirical studies showed that large companies have scale economies, however, scope economies have been largely are ignored as a creator of possible efficiencies.

Secondly, regarding the issue of ownership, there have been conducted a small number of studies that have considered the issues surrounding ownership. Based on these empirical studies, the results found that state-owned companies had a less efficient performance than private owned ones; foreign ownership control generally led to better managed companies compared to domestic owned ones; insider ownership adversely effected performance; and bank ownership of securities firms can lead to better management, and access to finance for the companies.

Finally, regulation has had a significant influence on the productivity/efficiency of the securities industry. Most of studies showed a positive impact of deregulation on performance.

To date the number of studies, and countries investigated, is limited and so therefore it would be expected that further research might be able to further clarify these results. Each issue examined needs to have further study given to it and it would be useful if these studies were extended to other countries. 


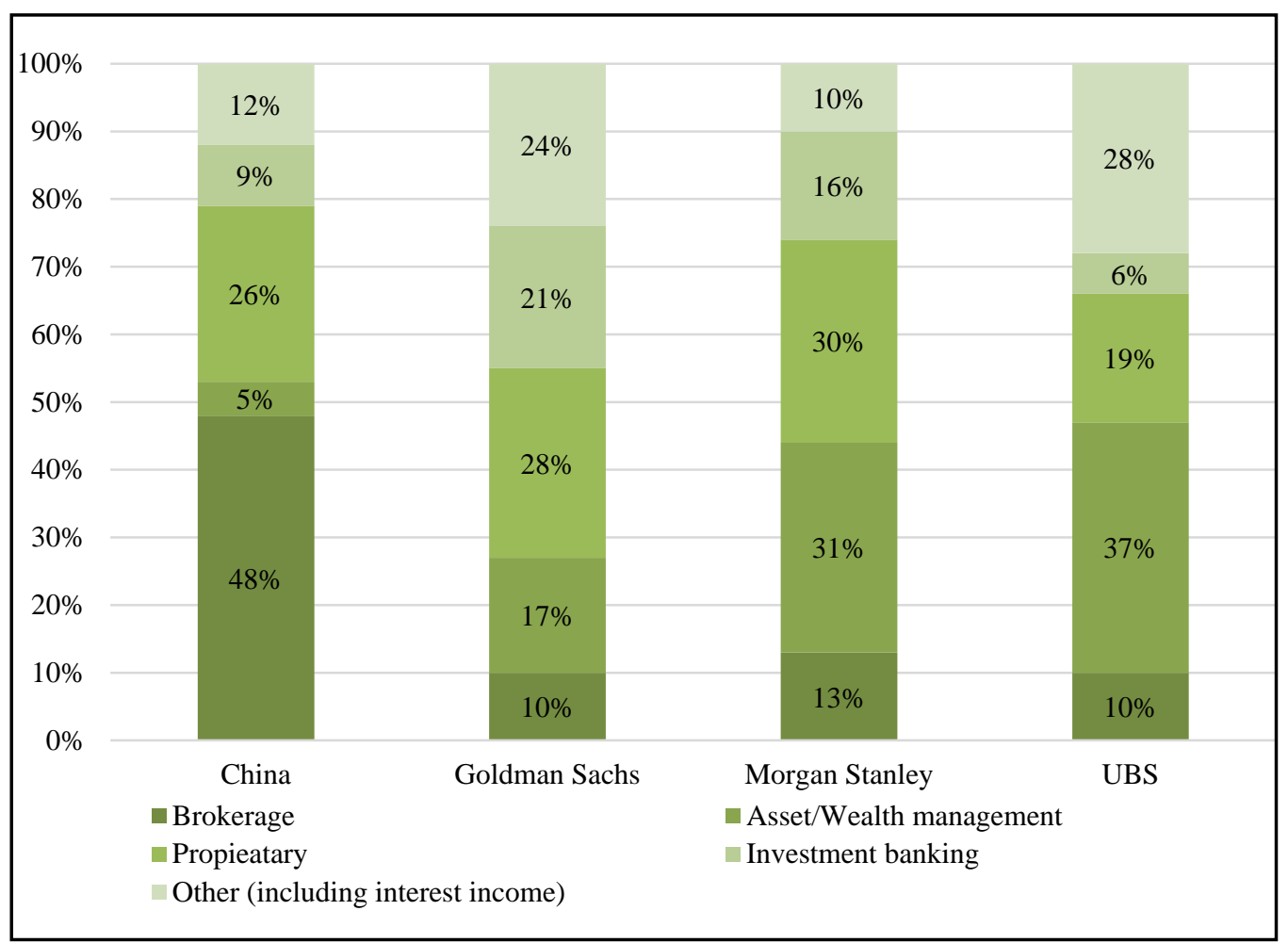

Figure 1. Income composition of securities companies, 2015

Source: KPMG (2015).

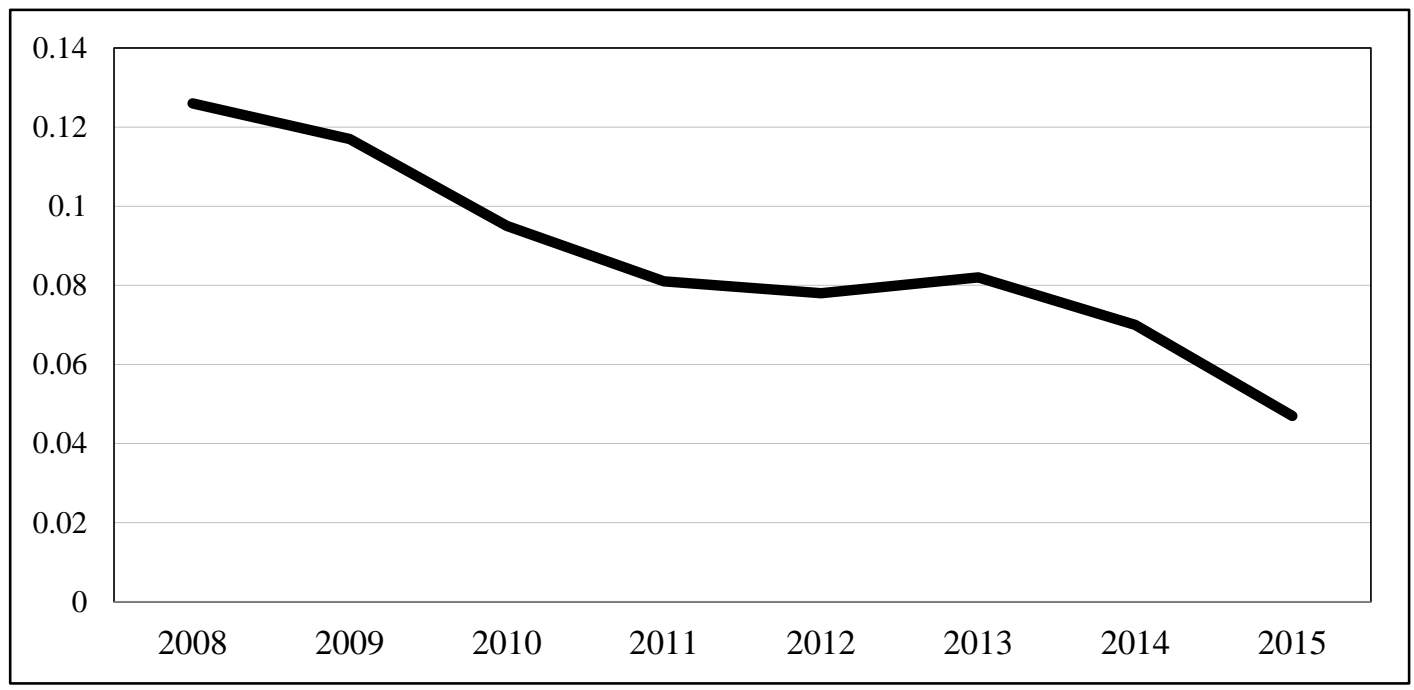

Figure 2. Average brokerage commision rate in the United States, 2008 to 2015 (per cent)

Source: Saunders and Cornett (2017), 115-116. 


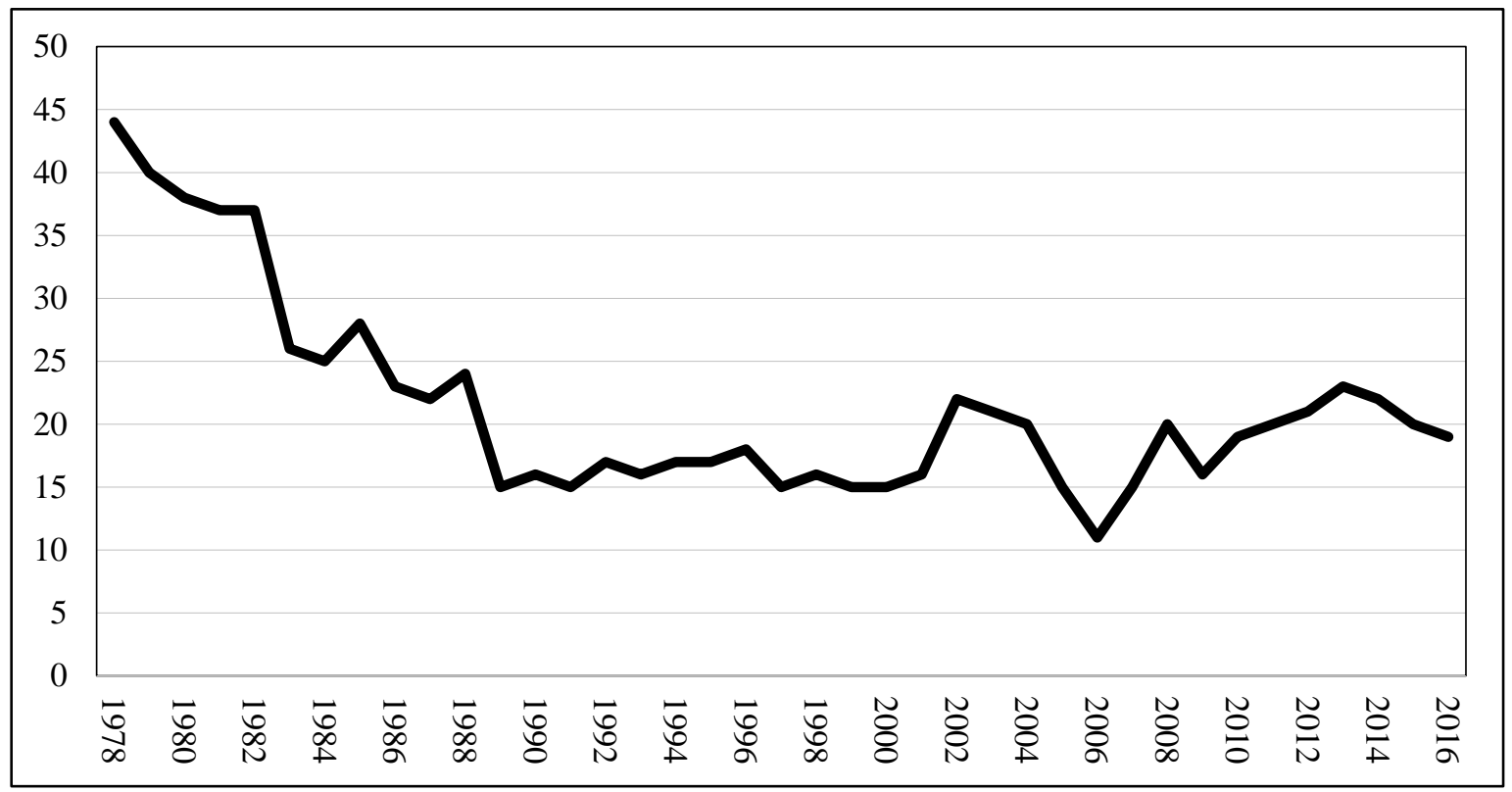

Figure 3. Commission income as a percentage of total revenues of securities companies in the United States, 1978 to 2016

Source: Saunders and Cornett (2017), Chapter 4, 115-116.

Table 1. Empirical studies on productivity and efficiency of securities industry

\begin{tabular}{|l|l|}
\hline Country & Study \\
\hline United States & $\begin{array}{l}\text { Williams (2009); Johnston and Madura (2000); Goldberg et.al. (1991); Lee, Kim and King (2014); McCauley } \\
\text { and Zimmer (1991); Zhang et al., 2006 }\end{array}$ \\
\hline $\begin{array}{l}\text { United } \\
\text { Kingdom }\end{array}$ & Ahmad and Lal (2006); Tanndal and Waldenstrom (2018); Hebb and Fraser (2003); Steeley (1992) \\
\hline Japan & Liu (2007); Fukuyama (2008); Fukuyama and Weber (1999) (2008); Harimaya and Okuyama (2006) \\
\hline China & Chen, Chen, Lin and Zhong (2005); Chen, Qi and Lin (2011); Bartholdy and Feng (2013) \\
\hline Taiwan & Hu and Fang (2010); Liao (2018); Yeh et al. (2010) \\
\hline Turkey & Demirbag, McGuinness, Akin and Bayyurt (2016); Bayyurt and Akin (2014) \\
\hline Vietnam & Nguyen et al. (2017), Wang et al. (2010) \\
\hline Korea & Song, Mantecon and Altintig (2012); Lee, Kim and Kang (2014) \\
\hline
\end{tabular}

Table 2A. Products sold by the financial services industry, 1950

\begin{tabular}{|c|c|c|c|c|c|c|c|c|}
\hline & $\begin{array}{c}\text { Payment } \\
\text { services }\end{array}$ & $\begin{array}{l}\text { Savings } \\
\text { products }\end{array}$ & $\begin{array}{c}\text { Fiduciary } \\
\text { services }\end{array}$ & $\begin{array}{c}\text { Business } \\
\text { lending }\end{array}$ & $\begin{array}{c}\text { Consumer } \\
\text { lending }\end{array}$ & $\begin{array}{c}\text { Underwrite } \\
\text { Equity }\end{array}$ & $\begin{array}{c}\text { Underwrite } \\
\text { debt }\end{array}$ & Insurance \\
\hline Banks & $\mathrm{X}$ & $\mathrm{X}$ & $\mathrm{X}$ & $\mathrm{X}$ & $\mathrm{X}$ & & & \\
\hline Insurance co. & & $\mathrm{X}$ & & & & & & $\mathrm{X}$ \\
\hline Finance co. & & & & & $\mathrm{X}$ & & & \\
\hline Securities co. & & $\mathbf{X}$ & $\mathbf{X}$ & & & $\mathbf{X}$ & $\mathbf{X}$ & \\
\hline Pension funds & & $\mathrm{X}$ & & & & & & \\
\hline Mutual funds & & $X$ & & & & & & \\
\hline
\end{tabular}

Table 2B. Products sold by the financial services industry, 2015

\begin{tabular}{|l|c|c|c|c|c|c|c|c|}
\hline & $\begin{array}{c}\text { Payment } \\
\text { services }\end{array}$ & $\begin{array}{c}\text { Savings } \\
\text { products }\end{array}$ & $\begin{array}{c}\text { Fiduciary } \\
\text { services }\end{array}$ & $\begin{array}{c}\text { Business } \\
\text { lending }\end{array}$ & $\begin{array}{c}\text { Consumer } \\
\text { lending }\end{array}$ & $\begin{array}{c}\text { Underwrite } \\
\text { Equity }\end{array}$ & $\begin{array}{c}\text { Underwrite } \\
\text { debt }\end{array}$ & $\begin{array}{c}\text { Insurance } \\
\text { Banks }\end{array}$ \\
\hline Insurance co. & $\mathrm{X}$ & $\mathrm{X}$ & $\mathrm{X}$ & $\mathrm{X}$ & $\mathrm{X}$ & $\mathrm{X}$ & $\mathrm{X}$ & $\mathrm{X}$ \\
\hline Finance co. & $\mathrm{X}$ & $\mathrm{X}$ & $\mathrm{X}$ & $\mathrm{X}$ & $\mathrm{X}$ & $\mathrm{X}$ & $\mathrm{X}$ & $\mathrm{X}$ \\
\hline Securities co. & $\mathrm{X}$ & $\mathrm{X}$ & $\mathrm{X}$ & $\mathbf{X}$ & $\mathbf{X}$ & $\mathrm{X}$ & $\mathrm{X}$ & $\mathrm{X}$ \\
\hline Pension funds & & $\mathrm{X}$ & $\mathrm{X}$ & & & & $\mathrm{X}$ \\
\hline Mutual funds & $\mathrm{X}$ & $\mathrm{X}$ & $\mathrm{X}$ & & & & $\mathrm{X}$ \\
\hline
\end{tabular}

Source: Lange et.al (2015) 


\section{References}

Ahmad, F., \& Lal, D. (2006). A review of financial and regulatory reforms in the gilt-edged market. Journal of Financial Regulation and Compliance, 14(2), 165-173. https://doi.org/10.1108/13581980610659477

Barros, C. P., Ferreira, c., \& Williams, J. (2007). Analyzing the determinants of performance of best and worst European banks: a mixed logit approach. Journal of Banking and Finance, 31, 2189-2203. https://doi.org/10.1016/j.jbankfin.2006.11.010

Bartholdy, J., \& Feng, T. (2013). The quality of securities firms' earnings forecasts and stock recommendations: do informational advantages, reputation and experience matter in China? Pacific-Basin Finance Journal, 24, 66-88. https://doi.org/10.1016/j.pacfin.2013.02.005

Bayyurt, N., \& Akin, A. (2014). Effects of foreign acquisitions on the performance of securities firms: evidence from Turkey. Procedia-Social and Behavioral Sciences, 150, 156-161. https://doi.org/10.1016/j.sbspro.2014.09.020

Chen, R., Qi, C. Z., \& Lin, T. W. (2011). Ownership structure and corporate governance among Chinese securities firms. International Journal of Management, 28(3), 789-805.

Chen, S. K., Chen, X., Lin, B., \& Zhong, R. (2005). The impact of government regulation and ownership on the performance of securities companies: evidences from China. Global Finance Journal, 16, 113-124. https://doi.org/10.1016/j.gfj.2005.06.001

Choi, S., \& Hasan, I. (2005). Ownership, governance, and bank performance: Korean experience. Financial Markets, Institutions and Instruments, 14(4), 215-242. https://doi.org/10.1111/j.0963-8008.2005.00104.x

Demirbag, M., McGuinness, M., Akin, A. Bayyurt, N., \& Basti, E. (2016). The professional service companies (PSF) in a globalised economy: a study of the efficiency of securities companies in an emerging market. International Business Review, 25, 1089-1102. https://doi.org/10.1016/j.ibusrev.2016.01.001

Fukuyama, H., \& Webber, W. (2007). Profit inefficiency of Japanese securities firms. Journal of Applied Economics, 11(2), 281-303. https://doi.org/10.1080/15140326.2008.12040508

Fukuyama, H., \& Webber, W. L. (1999). The efficiency and productivity of Japanese securities firms, 1988-93. Japan and the World Economy, 11, 115-133. https://doi.org/10.1016/S0922-1425(97)00033-9

Goldberg, L. G., Hanweck, G. A., Keenan, M., \& Young, A. (1991). Economies of scale and scope in the securities industry. Journal of Banking and Finance, 15, 91-107. https://doi.org/10.1016/0378-4266(91)90039-O

Harimaya, K., \& Okuyama, E. (2006). The changing structure of cost for Japanese securities firms. International Journal of Business, 11(1), 17-33.

Hebb, G. M., \& Fraser, D. R. (2003). Conflict of interest in commercial bank security underwritings: United Kingdom evidence. Quarterly Journal of Business and Economics, 42, 79-95.

Hu, F., \& Leung, S. C. M. (2012). Top management turnover, firm performance and government control: evidence from China's listed state-owned enterprises. International Journal of Accounting, 47(2), 235-262. https://doi.org/10.1016/j.intacc.2012.03.006

Hu, J., \& Fang, C. (2010a). Do market share and efficiency matter for each other? An application of the zero-sum gains data envelopment analysis. Journal of the Operational Research Society, 61, 647-657. https://doi.org/10.1057/jors.2009.11

Hu, J., \& Fang, C. (2010b). Managerial efficiency of securities firms under the law-induced financial holding companies in Taiwan. Journal of Information and Optimization Sciences, 31(1), 37-62. https://doi.org/10.1080/02522667.2010.10699944

Isik, I., \& Hassan, M. K. (2002). Technical, scale and allocative efficiencies of Turkish banking industry. Journal of Banking and Finance, 26(4), 719-766. https://doi.org/10.1016/S0378-4266(01)00167-4

Jensen, M. C., \& Meckling, W. H. (1976). Theory of the firm: Managerial behaviour, agency costs and ownership structure. Journal of Financial Economics, 3(4), 305-360. https://doi.org/10.1016/0304-405X(76)90026-X

Johnston, J., \& Madura, J. (2000). Valuing the potential transformation of banks into financial service conglomerates: evidence from the Citigroup merger. Financial Review, 35, 77-36. https://doi.org/10.1111/j.1540-6288.2000.tb01412.x

Kasman, A., \& Yildirim, C. (2006). Cost and profit efficiencies in transition banking: the case of new EU members. Applied Economics, 38, 1079-1090. https://doi.org/10.1080/00036840600639022

Lange H., Saunders A., \& Cornett M. M (2015). Financial institutions management: a risk management approach (4th 
ed.). Sydney: Mc-Graw Hill Education, Australia.

Lee, D., Kim, J., \& Kang, H. (2014). Do larger brokerage firms enjoy larger economies of scales and scope? Seoul Journal of Economics, 27(4), 445-467.

Lensink, R., \& Naaborg, I. (2007). Does foreign ownership foster bank performance? Applied Financial Economics, 17, 881-885. https://doi.org/10.1080/09603100600827653

Liao, C. (2018). Competition, contestability and market structure for securities firms in Taiwan. Asian Economic and Financial Review, 8(4), 499-514.

Liu, S. (2007). Commission deregulation and performance of securities firms: further evidence from Japan. Journal of Economics and Business, 60, 355-368. https://doi.org/10.1016/j.jeconbus.2007.03.005

McCauley, R. N., \& Zimmer, S. A. (1991). The cost of capital for securities firms in the United States and Japan. Federal Reserve Bank of New York Quarterly Review, 16(3), 14-27.

Mínguez-Vera, A., \& Martín-Ugedo, J. F. (2007). Does ownership structure affect value? A panel data analysis for the Spanish market. International Review of Financial Analysis, 16(1), 81-98. https://doi.org/10.1016/j.irfa.2005.10.004

Morck, R., Shleifer, A., \& Vishny, R. W. (1988). Management ownership and market valuation: an empirical analysis. Journal of Financial Economics, 20, 293-315. https://doi.org/10.1016/0304-405X(88)90048-7

Nguyen, T. H., Nguyen, X. M., Nguyen, T. T. H., \& Tran, Q. T. (2017). Ownership structure and performance of professional service firms in a declining industry: evidence from Vietnamese securities companies. Business and Economic Horizons, 13(2), 142-151. https://doi.org/10.15208/beh.2017.11

O’Brien, E. I. (1986). Financial deregulation: the securities industry perspective. New York Law School Law Review, 30, 271-280.

Omran, M. M., Bolbol, A., \& Fatheldin, A. (2008). Corporate governance and firm performance in Arab equity markets: Does ownership concentration matter? International Review of Law and Economics, 28 (1), 32-45. https://doi.org/10.1016/j.irle.2007.12.001

Sabi, M. (1996). Comparative analysis of foreign and domestic bank operations in Hungary. Journal of Comparative Economics, 22(2), 179-188. https://doi.org/10.1006/jcec.1996.0017

Saunders, A., \& Cornett, M. M. (2017). Financial institutions management: a risk management approach (9th ed.). New York: McGraw-Hill.

Shleifer, A., \& Vishny, R. W. (1986). Large shareholders and corporate control. Journal of Political Economy, 94(3), 461-488. https://doi.org/10.1086/261385

Song, K., Mantecon, T., \& Altintig, Z. A. (2012). Chaebol-affiliated analysist: conflicts of interest and market responses. Journal of Banking and Finance, 36, 584-596. https://doi.org/10.1016/j.jbankfin.2011.09.001

Steeley, J. M. (1992). Deregulation and market efficiency: evidence from the gilt-edged market. Applied Financial Economics, 2, 125-143. https://doi.org/10.1080/758516628

Tanndal, J., \& Waldenstrom, D. (2008). Does financial deregulation boost top incomes? Evidence from the Big Bang. Economica, 85, 232-265. https://doi.org/10.1111/ecca.12247

Wang, T., Chang, J., Truong, N. A., \& Chang, W. (2010). Applying TOPSIS method to evaluate the business operation performance of Vietnam listing securities companies. International Conference on Computational Aspects of Social Networks, 273-277. https://doi.org/10.1109/CASoN.2010.69

Whalen, G. (1999). Trends in organizational form and their relationship to performance: the case of foreign securities subsidiaries of U.S. banking organizations. Journal of Financial Services Research, 16, 181-218. https://doi.org/10.1023/A:1008140425342

Williams, J. W. (2009). Envisioning financial disorder: financial surveillance and the securities industry. Economy and Society, 38(3), 460-491. https://doi.org/10.1080/03085140903020663

Yeh, C., Wang, K., \& Chai, K. (2010). Measuring the efficiency of securities companies by corporate governance in a financial holding and non-financial holding system. Expert Systems with Applications, 37, 4671-4679. https://doi.org/10.1016/j.eswa.2009.12.041

Zhang, W. D., Zhang, S., \& Luo, X. (2006). Technological progress, inefficiency, and productivity growth in the US securities industry, 1980-2000. Journal of Business Research, 59, 589-594.

https://doi.org/10.1016/j.jbusres.2005.10.011 


\section{Appendix.}

Productivity and efficiency studies: methodology and results (by authors)

\begin{tabular}{|c|c|c|c|c|}
\hline Author & Date & Country & Methodology & Results \\
\hline Liao, C. & 2018 & $\begin{array}{l}\text { Taiwan, } 97 \text { companies, } \\
\text { 1998-2006 }\end{array}$ & $\begin{array}{lr}\text { OLS } & \text { regression, } \\
\text { partial } & \text { translog } \\
\text { functions } & \end{array}$ & $\begin{array}{l}\text { Market share positively related to profitability, but } \\
\text { negatively related to efficiency. }\end{array}$ \\
\hline Nguyen et al. & 2017 & $\begin{array}{l}\text { Vietnam, } 56 \\
\text { companies, } 2009-2016\end{array}$ & $\begin{array}{l}\text { Financial ratios }- \\
\text { OLS regression }\end{array}$ & $\begin{array}{l}\text { A significant negative relationship between insider } \\
\text { ownership and profitability. Foreign ownership has a } \\
\text { positive relationship with firm performance. }\end{array}$ \\
\hline $\begin{array}{l}\text { Demirbag et } \\
\text { al. }\end{array}$ & 2016 & $\begin{array}{l}\text { Turkey, } 85 \text { companies, } \\
\text { 2005-2011 }\end{array}$ & DEA & $\begin{array}{l}\text { A strong positive relationship between size and } \\
\text { efficiency in economies of scale in securities } \\
\text { companies. }\end{array}$ \\
\hline $\begin{array}{l}\text { Bayyurt, N. } \\
\text { and Akin, A. }\end{array}$ & 2014 & $\begin{array}{l}\text { Turkey, } 121 \\
\text { companies, } 2005-2011\end{array}$ & $\begin{array}{l}\text { DEA, panel } \\
\text { regression }\end{array}$ & $\begin{array}{l}\text { Foreign acquisition has a positive significant } \\
\text { contribution to the efficiency of securities companies. }\end{array}$ \\
\hline Lee et al. & 2014 & $\begin{array}{lrr}\text { Korea, } & 26 & \text { companies } \\
\text { and } & 9 & \text { banks, } \\
2000-2007 & \end{array}$ & $\begin{array}{ll}\text { Cobb-Douglas, } & \\
\text { translog } & \text { and } \\
\text { quadratic } & \text { cost } \\
\text { function } & \end{array}$ & $\begin{array}{l}\text { The industrial restructuring through M\&A among } \\
\text { brokerage companies and firm sizes impacted on } \\
\text { economies of scale and scope of securities companies. }\end{array}$ \\
\hline $\begin{array}{l}\text { Bartholdy, J. } \\
\text { and Feng, T. }\end{array}$ & 2013 & $\begin{array}{l}\text { China, } 90 \text { companies, } \\
\text { 2002-2009 }\end{array}$ & Financial ratios & $\begin{array}{l}\text { The quality of securities companies biased upward } \\
\text { earnings forecasts and stock recommendations based on } \\
\text { informational advantages, reputation and experience. }\end{array}$ \\
\hline Chen et al. & 2011 & $\begin{array}{l}\text { China, } 369 \text { companies, } \\
\text { 2003-2005 }\end{array}$ & Econometrics & $\begin{array}{l}\text { Ownership structure has an impact on the efficiency and } \\
\text { effectiveness of corporate governance of securities } \\
\text { companies. }\end{array}$ \\
\hline Song et al. & 2012 & $\begin{array}{l}\text { Korea, } 25-35 \\
\text { companies, } 2000-2008\end{array}$ & Financial ratios & $\begin{array}{l}\text { The analysts' reports of business group (industrial } \\
\text { companies and securities companies are affiliated and } \\
\text { operated within a same group) are biased by conflicts of } \\
\text { interest. }\end{array}$ \\
\hline $\begin{array}{l}\mathrm{Hu}, \quad \text { J. and } \\
\text { Fang, C. }\end{array}$ & 2010 & $\begin{array}{l}\text { Taiwan, } 266 \\
\text { companies, } 2001-2005\end{array}$ & DEA & $\begin{array}{l}\text { Foreign-affiliated ownership of securities companies } \\
\text { positively affects efficiency scores. }\end{array}$ \\
\hline $\begin{array}{l}\text { Hu, J. and } \\
\text { Fang, C. }\end{array}$ & 2010 & $\begin{array}{lr}\text { Taiwan, } & 12-14 \\
\text { integrated } & \text { securities } \\
\text { companies, } & 2002-2005\end{array}$ & DEA & $\begin{array}{l}\text { Financial holding companies have negatively impact on } \\
\text { the managerial efficiency of securities companies and } \\
\text { also increase the incentives for efficiency in the whole } \\
\text { securities industry. }\end{array}$ \\
\hline Yeh et al. & 2010 & $\begin{array}{l}\text { Taiwan, } 26 \text { companies, } \\
\text { 2001-2007 }\end{array}$ & $\begin{array}{l}\text { DEA, } \\
\text { regression }\end{array}$ & $\begin{array}{l}\text { Securities companies may be enhanced operational } \\
\text { efficiency when joining the financial holding system. } \\
\text { No correlation between large size and efficiency. }\end{array}$ \\
\hline $\begin{array}{l}\text { Fukuyama, H. } \\
\text { and Weber, } \\
\text { W. }\end{array}$ & 2008 & $\begin{array}{l}\text { Japan, } \quad 41-52 \\
\text { companies, } 1989-2005\end{array}$ & DEA & $\begin{array}{l}\text { Allocative inefficiency dominated technical } \\
\text { inefficiency, and both led to profit inefficiency. }\end{array}$ \\
\hline Liu, S. & 2007 & $\begin{array}{l}\text { Japan, } 15 \text { companies, } \\
\text { 1994-1999 }\end{array}$ & Financial ratios & $\begin{array}{l}\text { Securities companies' stock performance tends to } \\
\text { decline as the deregulation proceeds. }\end{array}$ \\
\hline Zhang et al. & 2006 & $\begin{array}{l}\text { US, range from } \\
386-271 \text { companies } \\
\text { from } 1980-2000\end{array}$ & DEA Malmquist & $\begin{array}{l}\text { United States securities industry was quite } \\
\text { cross-sectionally inefficient. The productivity of the } \\
\text { securities industry in general declined. }\end{array}$ \\
\hline $\begin{array}{l}\text { Harimaya, K. } \\
\text { and Okuyama, } \\
\text { E. }\end{array}$ & 2006 & $\begin{array}{l}\text { Japan, range from } \\
56-53 \quad \text { companies, } \\
1998-2002\end{array}$ & $\begin{array}{l}\text { Generalised translog } \\
\text { cost function }\end{array}$ & $\begin{array}{l}\text { The changing structure of securities companies by } \\
\text { deregulation led the online ones to have economies of } \\
\text { scale as a whole. Significant relationship between } \\
\text { product-specific economies of scale and brokerage } \\
\text { commissions. }\end{array}$ \\
\hline Chen et al. & 2005 & $\begin{array}{l}\text { China, } 75 \text { companies, } \\
2000-2001\end{array}$ & $\begin{array}{l}\text { Financial ratios } \\
\text { regression }\end{array}$ & $\begin{array}{l}\text { Direct government ownership did not improve the } \\
\text { performance of securities companies, regulation did. }\end{array}$ \\
\hline $\begin{array}{l}\text { Johnston, J. } \\
\text { and Madura, } \\
\text { J. }\end{array}$ & 2000 & $\begin{array}{l}\text { US, } 72 \text { banks, } 26 \\
\text { insurance } \\
24 \quad \text { companies, } \\
\text { companies, January } 8- \\
\text { July 1, } 1998 \text { (121 days) }\end{array}$ & $\begin{array}{l}\text { Multivariate } \\
\text { regression model, } \\
\text { cross-sectional } \\
\text { model }\end{array}$ & $\begin{array}{l}\text { Commercial banks, insurance companies, and brokerage } \\
\text { companies had positive and significant valuation in } \\
\text { cross-selling and efficiencies from diversification across } \\
\text { financial services resulted from Citigroup merger. } \\
\text { Larger banks had more favourable valuation effects than } \\
\text { the smaller ones. }\end{array}$ \\
\hline $\begin{array}{l}\text { Fukuyama, H. } \\
\text { and Weber, } \\
\text { W. }\end{array}$ & 1999 & $\begin{array}{l}\text { Japan, } 57 \text { companies, } \\
\text { 1988-1993 }\end{array}$ & DEA Malmquist & $\begin{array}{l}\text { Deregulation led to cost-efficiency: technical efficiency, } \\
\text { allocative efficiency, congestion efficiency, and scale } \\
\text { efficiency. The size of securities companies (big four } \\
\text { companies) has cost-efficient advantage over smaller } \\
\text { ones. }\end{array}$ \\
\hline Steeley, J. M. & 1992 & $\begin{array}{l}\text { UK, } 45 \text { gilt stocks, } \\
\text { daily data from } 28 \\
\text { October } 1985 \text { to } 16\end{array}$ & $\begin{array}{l}\text { Time series analysis } \\
\text { and cross-sectional } \\
\text { pricing efficiency }\end{array}$ & $\begin{array}{l}\text { Deregulation improved operational efficiency, and } \\
\text { informational efficiency in gilt-edged securities market. }\end{array}$ \\
\hline
\end{tabular}




\begin{tabular}{|l|l|l|l|l|}
\hline & & October 1987 & & \\
\hline $\begin{array}{l}\text { Goldberg et } \\
\text { al. }\end{array}$ & 1991 & $\begin{array}{l}\text { United States, 68 } \\
\text { companies, 1980-83 }\end{array}$ & $\begin{array}{l}\text { Multiproduct, } \\
\text { translog } \\
\text { function }\end{array}$ & $\begin{array}{l}\text { Small companies had economies of scale, large and } \\
\text { diverse companies had diseconomies of scale. } \\
\text { Economies of scope was unimportant in the industry } \\
\text { this period. }\end{array}$ \\
\hline $\begin{array}{l}\text { McCauley, R. } \\
\text { N. and } \\
\text { Zimmer, S. A. }\end{array}$ & 1991 & $\begin{array}{l}\text { United States, five } \\
\text { United States } \\
\text { companies and four } \\
\text { Japanese companies, } \\
\text { 1982-91 }\end{array}$ & $\begin{array}{l}\text { Financial ratios } \\
\text { hurdle in pricing products and services, disadvantage in } \\
\text { competition. Household savings, economic growth and } \\
\text { safety net had relationship with equity costs. }\end{array}$ \\
\hline
\end{tabular}

\section{Copyrights}

Copyright for this article is retained by the author(s), with first publication rights granted to the journal.

This is an open-access article distributed under the terms and conditions of the Creative Commons Attribution license which permits unrestricted use, distribution, and reproduction in any medium, provided the original work is properly cited. 